\title{
MJFAS MALAYSIAN JUURNAL OF

\section{Optimization and effect of supercritical carbon dioxide extraction conditions on global oil yield and eugenol from piper betle leaves}

\author{
Nur Husnina Arsad a, b, ${ }^{\star}$, Mohd A. Che Yunus ${ }^{a, b}$, Zuhaili Idham a, b \\ a Centre of Lipid Engineering and Applied Research (CLEAR), Ibnu Sina Institute for Scientific and Industrial Research, Universiti Teknologi \\ Malaysia, Skudai 81310, Johor, Malaysia \\ b Faculty of Chemical and Energy Engineering, Universiti Teknologi Malaysia, 81310 UTM Johor Bahru, Johor, Malaysia
}

* Corresponding author: ninarsd@gmail.com.my

\section{Article history}

Received 19 November 2017

Accepted 15 December 2017

\section{Graphical abstract}

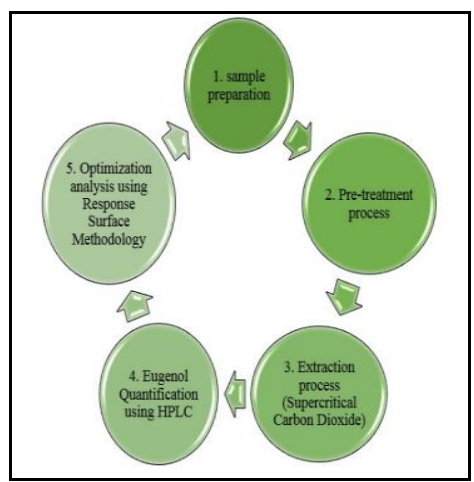

\begin{abstract}
Todays, medicinal plants have been of great importance to the health of people and societies in Malaysia, and the entire world. Piper betle leaves, a member of family Piperaceae is an edible plant. The leaves of Piper betle have been traditionally utilized in India for inhibition of oral diseases. Scientific research shows that the leaves possess many biological activities with a good medicinal and commercial value. Nowadays, advance technologies have been used to develop high quality products. This study concentrates on supercritical fluid extraction technology which carbon dioxide, $\mathrm{CO}_{2}$ play as a solvent. The purpose of this study was to optimize and look into the effects of supercritical $\mathrm{CO}_{2}$ (SC-CO2) extraction process variables, namely pressure (10-30 MPa), temperature $\left(40-80^{\circ} \mathrm{C}\right)$ and $\mathrm{CO}_{2}$ flowrate $(2-8 \mathrm{~mL} / \mathrm{min})$ on global oil yield and percentage of Eugenol in Piper betle Leaves. The result shows that as the pressure, temperature and flow rate of $\mathrm{CO}_{2}$ increased the oil yield of Piper betle leaves increased. However, further increased, resulting in decreasing the amount of global oil yield. Meanwhile, the percentage of Eugenol increased as the $\mathrm{CO}_{2}$ flow rate increased. However, as the pressure and temperature increased, the percentage of Eugenol decreased. Second order polynomial model was used to express the extracted oil and percentage of Eugenol with the both results was satisfactory. The best conditions to maximize the global oil yields and percentage of Eugenol extracted were $19.0 \mathrm{MPa}, 40.0^{\circ} \mathrm{C}$ and $7.0 \mathrm{~mL} / \mathrm{min}$ leading to $0.228 \mathrm{~g}$ of oil and $8.21 \%$ of Eugenol. The most dominant factor for both responses was $\mathrm{CO}_{2}$ flowrate. The results show a good fit to the proposed model and the optimal conditions obtained were within the experimental range with the value of $R^{2}$ was $69.06 \%$ for global oil yield and $82.79 \%$ for amount of Eugenol.
\end{abstract}

Keywords: Supercritical carbon dioxide extraction, Piper betle Leaves, Piperaceae, Optimization, Eugenol

(C) 2017 Penerbit UTM Press. All rights reserved

\section{INTRODUCTION}

Currently the studies on natural products are one of the most coveted research in this universe. As we cognize, plant based products have been expended throughout the world to treat many diseases. It is therefore important to establish their quality. In this study we selected widely available plant namely Piper betle leaves. This plant is locally known as 'Sirih' and belongs to the genus Piper of Piperaceae family [1]. The betel plant is a stunning and aromatic creeper. It has an alternate, heart shaped, smooth, shining, and long stalked leaves with pointed apex. This plant arose from the central and eastern part of Peninsular Malaysia [2]. Today, this plant is extensively cultivated by thousands of betel growers in various parts of India where about 40 varieties are found in India and more so 30 in West Bengal [3-5].

Several constituents have been identified in leaf oils of Piper betle depending on the predominance of compounds such as alkaloid/amide group [6], propenylphenol group [7], prenylated hydroxybenzoic acid group [8], terpene/sesquiterpene group and steroid group [9]. Eugenol $\left(\mathrm{C}_{10} \mathrm{H}_{12} \mathrm{O}_{2}\right)$ has been regarded as the major volatile of essential oil compounds belonging to the propenylphenol group. Eugenol $\left(\mathrm{C}_{10} \mathrm{H}_{12} \mathrm{O}_{2}\right)$ that present in Piper betle leaves was bacteriostatic and fungistatic [10-12]. The chemical structures of Eugenol are shown in
Fig. 1. To date, Eugenol $\left(\mathrm{C}_{10} \mathrm{H}_{12} \mathrm{O}_{2}\right)$ is utilized as an analgesic in dental preparations, as an insect repellent and as a flavoring agent in foods [13]. The FDA permitted its use in foods and status of GRAS (generally regarded as safe) was appointed by the Flavor and Extract Manufacturers Association. Eugenol $\left(\mathrm{C}_{10} \mathrm{H}_{12} \mathrm{O}_{2}\right)$ also has been reported shown to possess anti-inflammatory effects in various animal models of studies with various inflamogens [14]. It has a long antiquity of use as a major and active ingredient in traditional medicines. [15].

Supercritical fluid extraction has developed as an attractive separation system for the food and pharmaceutical industries due to a growing necessitate for "natural" processes that do not bring in any residual organic chemicals. Supercritical carbon dioxide $\left(\mathrm{SC}-\mathrm{CO}_{2}\right)$ extraction is extensively used as an alternative technique in nutraceuticals industry because of the comparatively low critical temperature $\left(\mathrm{Tc}=31^{\circ} \mathrm{C}\right)$, inertness, and non-toxicity of carbon dioxide $\left(\mathrm{CO}_{2}\right)$ [16-17]. SC-CO $\mathrm{CO}_{2}$ extraction processes are generally carried out at near-environmental temperatures and in the nonexistence of air, which lessens heat requirements, and avoids thermal and oxidative impairment of labile compounds [18-19] Furthermore, one of the main benefits of this technology is the capability of the process in varying the pressure and temperature in order to modify the fluid density. 
Hence, supercritical fluids are frequently used to extract selectively or separate specific compounds from a mixture [20].

In industrial perspective, enhancing the extraction process and recovery of target compound is important. Therefore, in supercritical fluid extraction (SFE) process, optimization of the process condition is one of the main aspects that should be studied. Response surface methodology (RSM) is a set of techniques used in industrial process control and engineering to find the best levels of input variables of a response [21]. This experimental methodology combines mathematics with statistics for producing a mathematical model to depict the process, studying the effects of the independent variables and optimizing the processing operations [22].

Comparing the RSM method and other method such as Taguchi method, it shows that RSM is more capable due to its giving very low average error towards modelling and experimental validation as well as the significance of interactions and square terms of parameters are more undoubtedly predicted in RSM [23]. RSM has a major advantage over the one-factor-a time approach in that it lets the assessment of the effect of multiple variables and their interactions on the output variables with lessened number of tests [24]. RSM has been successfully applied to model and optimize supercritical $\mathrm{CO}_{2}$ extraction of oils from Swietenia Mahagoni Seed [25], Quercus infectoria [26] and squalene from palm oil [27].

Hence, using RSM in $\mathrm{SC}-\mathrm{CO}_{2}$ process would be an outstanding method to optimize the extraction and, by manipulating the combined arrangement of pressure, temperature and flowrate. Thus, the objective of this study was to optimize the extracted yield and concentration of Eugenol from Piper betle leaves using $\mathrm{SC}-\mathrm{CO}_{2}$.

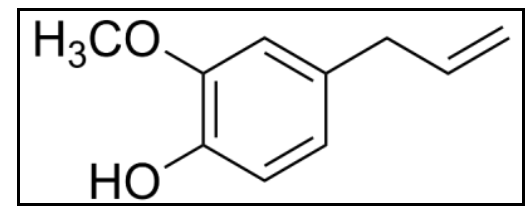

Fig. 1 Structure of Eugenol

\section{METHODOLOGY}

\section{Sample Preparation}

The fresh leaves of Piper betle were collected in bulk from Banting, Selangor, Malaysia. The leaves were separated from the stalks and washed thoroughly with distilled water to remove any dirt and dust present. The clean leaves were cut into small pieces and were dried at $40{ }^{\circ} \mathrm{C}$ for 12 hours. The dried leaves were ground just before extraction in a grinder (mill machine, Pulverisett 14, Ider- Oberstein, Germany) to produce a powder with an approximate particle size of $355 \mu \mathrm{m}$ and stored at $0-5^{\circ} \mathrm{C}$ prior to use.

\section{Supercritical Carbon Dioxide System}

In this study, SFX TM 220 extraction system (ISCO, Lincoln, NE, US) comprising of high pressure syringe pump (Model: OM51K40GN-CW2), $10 \mathrm{~mL}$ stainless steel extraction cell, extractor chamber, extractor controller (Model: TESCOM 10000), a chiller (Model: Wisezcircu) and $\mathrm{CO}_{2}$ with $99.99 \%$ purity (MOX Gases Sdn. Bhd. Selangor) as a solvent were used throughout the process. The equipment set up of the extraction process SFX TM 220 is shown in Fig. 2.

$5.0 \mathrm{~g}$ of ground dried Piper betle leaves that have reached room temperature were loaded into the extraction cell and tightly sealed. Next, the extraction cell was set in the extraction chamber and let the system to reach the desired condition. The extraction started after reaching the desired condition. Volume of $\mathrm{CO}_{2}$ used and extracted oil was recorded every 30 minutes of the extraction process. The extraction duration was 3 hours and 30 minutes. Extracts are finally separated from the $\mathrm{CO}_{2}$ phase and collected in collector at ambient temperature and atmospheric pressure. The $\mathrm{CO}_{2}$ gas was depressurized to remove from the separator.

\section{Experimental Design}

An experimental design was performed to optimize three important parameters of SC- $\mathrm{CO}_{2}$ extraction which are flowrate of $\mathrm{CO}_{2}$ $\left(\mathrm{X}_{1}\right)$, temperature $\left(\mathrm{X}_{2}\right)$ and pressure $\left(\mathrm{X}_{3}\right)$ at constant average particle size and extraction time to achieve high percentage of global oil and high percentage of Eugenol $\left(\mathrm{C}_{10} \mathrm{H}_{12} \mathrm{O}_{2}\right)$ from Piper betel extracts.

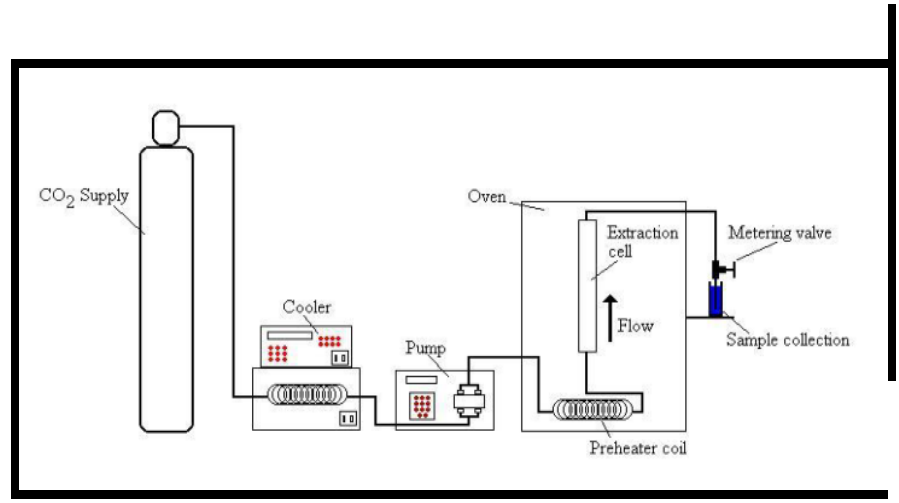

Fig. 2 Schematic diagrams of Supercritical fluid extraction apparatus

Response surface methodology (RSM) was applied to analyzing the effect of the three factors on the two responses and identify the combination that will optimize the extraction. Historical data Design was used to perform this experiment. The parameters were assigned at three coded levels of $-1,0$ and +1 for temperature of 40, 60 and 80 ${ }^{\circ} \mathrm{C}$, pressure of 10, 20 and $30 \mathrm{Mpa}$, and flowrate of $\mathrm{CO}_{2}$ of 4,6 and 8 $\mathrm{mL} / \mathrm{min}$. The result obtained were analysed using Design Expert version 6.0.4.

The coded and uncoded independent variables employed in RSM design are shown in Table 1. The experimental points used according to this design are shown in Table 2 where $\mathrm{Y}_{1}$ represent oil yield and $\mathrm{Y}_{2}$ represent percentage of Eugenol $\left(\mathrm{C}_{10} \mathrm{H}_{12} \mathrm{O}_{2}\right)$ of Piper betle leaves extracted. In the research, the experimental data were fitted with the second order polynomial model which indicated a requirement of 27 experiments to cover all possible combinations of factors levels. The general equation of the second-degree polynomial is stated as follows:

$Y=\beta_{0}+\sum_{i=1}^{k} \beta_{i} x_{i}+\sum_{i=1}^{k} \beta_{i i} x_{i}^{2}+\sum \sum_{i<j}^{k} \beta_{i j} x_{i} x_{j}+\epsilon$

Where the $\beta_{i}$ are the regression coefficients for the first-degree terms, the $\beta_{\mathrm{ii}}$ are coefficients for the pure quadratic terms, the $\beta_{\mathrm{i} j}$ are the coefficients for the cross-product terms, and $E$ is the random error term

Table 1 Experimental levels of the factors

\begin{tabular}{|c|c|c|c|c|}
\hline \multirow{2}{*}{ Symbol } & \multirow{2}{*}{$\begin{array}{c}\text { Independent } \\
\text { Variables }\end{array}$} & \multicolumn{3}{|c|}{ Coded Level } \\
\hline & & -1 & 0 & +1 \\
\hline \multicolumn{5}{|c|}{ Factor Level } \\
\hline$X_{1}$ & $\begin{array}{l}\text { Flowrate } \\
\text { (mL/min) }\end{array}$ & 4 & 6 & 8 \\
\hline$X_{2}$ & $\begin{array}{l}\text { Temperature } \\
\left({ }^{\circ} \mathrm{C}\right)\end{array}$ & 40 & 60 & 80 \\
\hline$x_{3}$ & $\begin{array}{l}\text { Pressure } \\
\text { (MPa) }\end{array}$ & 10 & 20 & 30 \\
\hline
\end{tabular}


Table 2 Experimental and estimated values for different levels of experimental design

\begin{tabular}{cccll}
\hline$X_{1}$ & $X_{2}$ & $X_{3}$ & \multicolumn{1}{c}{$Y_{1}$} & \multicolumn{1}{c}{$Y_{2}$} \\
\hline-1 & 0 & -1 & 0.1927 & 6.3273 \\
-1 & 0 & 0 & 0.2385 & 6.4179 \\
-1 & 0 & 1 & 0.126 & 5.3768 \\
-1 & 1 & -1 & 0.2351 & 5.9418 \\
-1 & 1 & 0 & 0.2473 & 5.6038 \\
-1 & 1 & 1 & 0.0879 & 6.2379 \\
-1 & -1 & -1 & 0.1672 & 8.1849 \\
-1 & -1 & 0 & 0.2228 & 6.5266 \\
-1 & -1 & 1 & 0.0927 & 6.2179 \\
0 & 0 & -1 & 0.2071 & 7.5693 \\
0 & 0 & 0 & 0.2577 & 6.0849 \\
0 & 0 & 1 & 0.2983 & 5.1617 \\
0 & 1 & -1 & 0.1804 & 8.7075 \\
0 & 1 & 0 & 0.1952 & 7.2734 \\
0 & 1 & 1 & 0.2384 & 6.3968 \\
0 & -1 & -1 & 0.2065 & 7.7344 \\
0 & -1 & 0 & 0.2427 & 6.5930 \\
0 & -1 & 1 & 0.276 & 6.2521 \\
1 & 0 & -1 & 0.1402 & 10.231 \\
1 & 0 & 0 & 0.1776 & 9.1760 \\
1 & 0 & 1 & 0.1917 & 8.5523 \\
1 & 1 & -1 & 0.1725 & 9.2323 \\
1 & 1 & 0 & 0.1908 & 8.2770 \\
1 & 1 & 1 & 0.2502 & 6.0574 \\
1 & -1 & -1 & 0.1636 & 8.7878 \\
1 & -1 & 0. & 0.2439 & 6.6748 \\
1 & -1 & 1 & 0.361 & 3.5580 \\
\hline & & & &
\end{tabular}

\section{Eugenol Determination}

Identification and Quantification of Eugenol was performed using Agilent Eclipse Plus C18 (150 x $4.6 \mathrm{~mm}$ I.D., particle size $5 \mu \mathrm{m})$ (Agilent Technologies, California, USA). A reverse-phase HPLC assay was carried out using an isocratic system with a flow rate of 1.0 $\mathrm{mL} / \mathrm{min}$, a column temperature of $25^{\circ} \mathrm{C}$ and a mobile phase of acetonitrile: methanol $(85: 15, \mathrm{v} / \mathrm{v})$. The peaks were detected at 280 $\mathrm{nm}$ and identified using reference standards of Eugenol. A quantitative determination of Eugenol was completed by comparison of the peak area of the sample injection to the corresponding peak area of a standard injection. Identification of Eugenol from $\mathrm{SC}^{-\mathrm{CO}_{2}}$ extraction of Piper betle leaves were made by comparing the chromatographic appearance of the peak and retention time of standards reference as presented in Fig. 3.

\section{RESULTS AND DISCUSSION}

As referred earlier, a RSM was applied to measure, both, the main and the relations effects of the operating parameters. In this research, the RSM was employed to create and discover an estimated functional connection among variables such as temperature, pressure and flow rate of $\mathrm{CO}_{2}$ utilized with yield of global oil and chemical compound extracted. The pressure studied was in the range of 10 to $30 \mathrm{MPa}$ and the temperature studied was in the range of 40 and $80{ }^{\circ} \mathrm{C}$ while the flow rate of $\mathrm{CO}_{2}$ studied was between 4 to $8 \mathrm{~mL} / \mathrm{min}$ (Table 1 ).

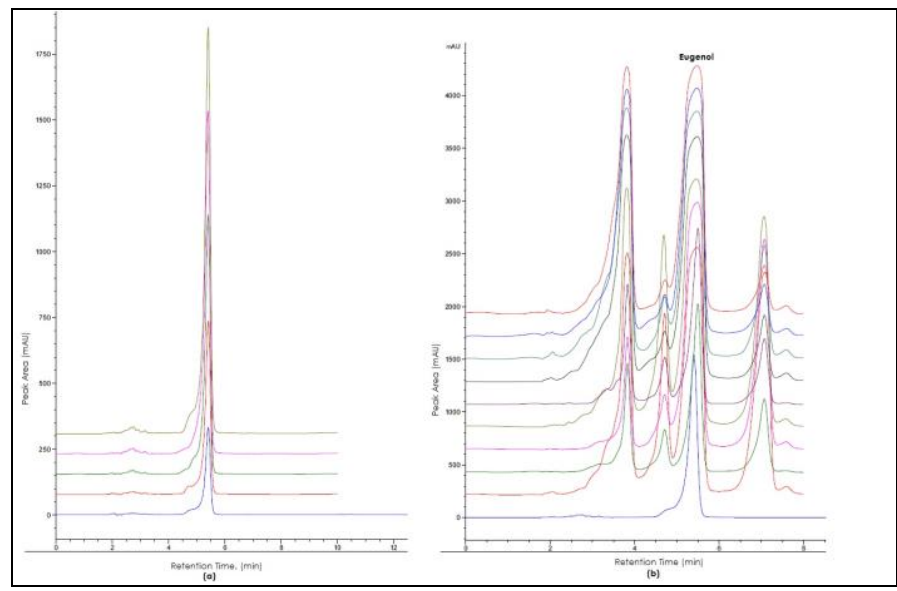

Fig. 3 HPLC chromatograms of Eugenol: (a) standard Mixture and (b) $\mathrm{SC}-\mathrm{CO}_{2}$ extract of Piper betle leaves

The oil yield and percentage of Eugenol obtained from all the experiments is listed in Table 2 according to RSM design. From the data obtained, the highest global oil yield of piper betel extracts was $0.361 \mathrm{~g}$ at high conditions of $\mathrm{SC}-\mathrm{CO}_{2}$ process where temperature at 80 ${ }^{\circ} \mathrm{C}$, pressure at $30 \mathrm{MPa}$ and flow rate of $\mathrm{CO}_{2}$ at $8 \mathrm{~mL} / \mathrm{min}$.

Fig. 4 shows three-dimensional plot of the response surface for global oil yield for which the polynomial function is

$$
\begin{aligned}
& \text { Oil yield }(\mathrm{g})=0.413+0.032 \mathrm{f}-0.00976 \mathrm{f}^{2}-0.0082 \mathrm{~T} \\
& +0.000029 \mathrm{~T}^{2}-0.00696 \mathrm{P}-0.00025 \mathrm{P}^{2}+0.0000695 \mathrm{fT} \\
& +0.00256 \mathrm{P}+0.002 \mathrm{fP}^{2}-0.000049 \mathrm{TP}
\end{aligned}
$$

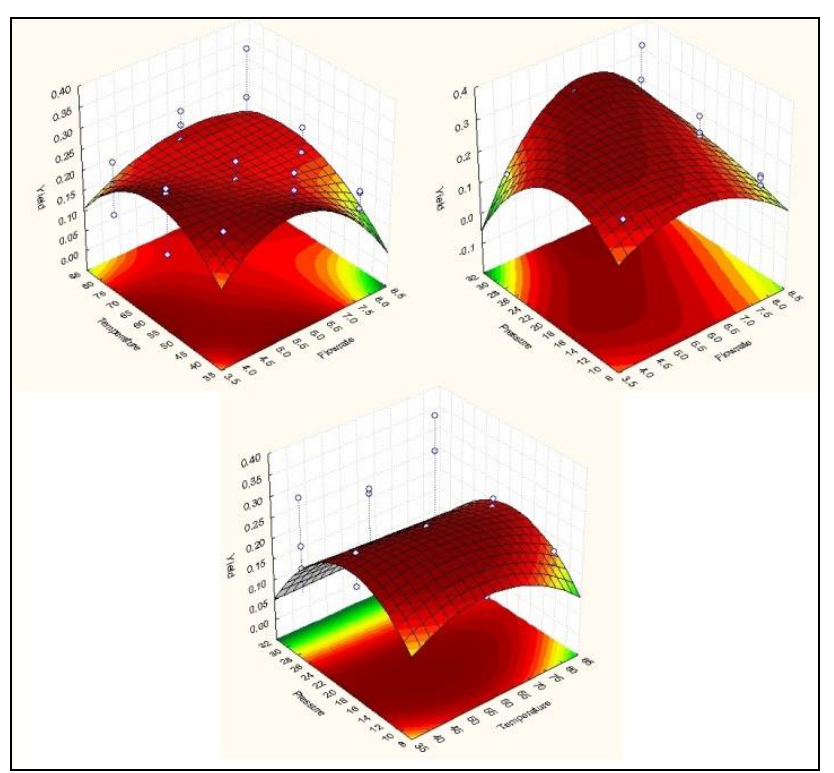

Fig. 4 Three-dimensional plot of the response surface for global oil yields of Piper Betle leaves

As can be seen in Eq. 2, the flow rate of $\mathrm{CO}_{2}$ shows the most dominant parameter which contributes positive effect with the coefficient of 0.032 compared with pressure and temperature where the coefficient obtained is 0.00696 and 0.0082 . From the graph shown in Fig. 4, mostly all the relations between the parameters were in quadratic pattern. As the pressure, temperature and flow rate of $\mathrm{CO}_{2}$ increased the global oil yield of Piper betle leaves increased. However, further increased, resulting in decreasing the amount of global oil yield.

This phenomenon occurs most likely due to the increasing the $\mathrm{CO}_{2}$ solvent density as the pressure increased that resulting in an improvement in solvent power [28]. However, the declining of oil yield with further increasing the pressure probably a reflection of the 
increased repulsive solute-solvent interactions resulted from the highly compressed carbon dioxide at high-pressure levels.

Next, the progressive effect of temperature can be described in reference to its power to modify the physical properties of the sample matrix, causing it accessible for the $\mathrm{CO}_{2}$ to perforate that resulting in increasing the mass transfer speed. However, declining of oil yield with further increase of temperature most probably because the density of the supercritical fluid decreased at a higher temperature.

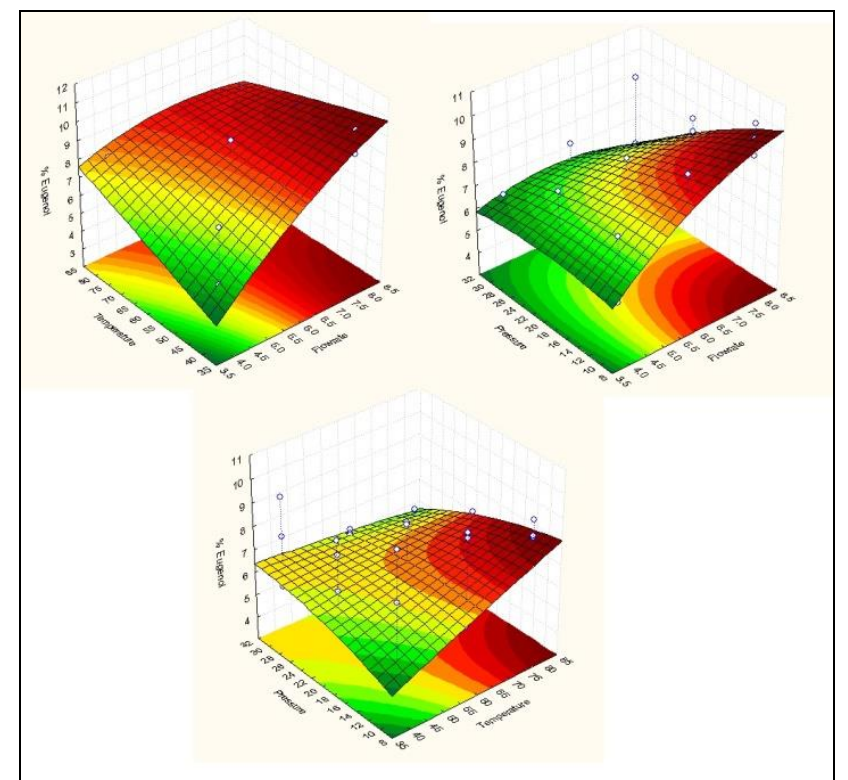

Fig. 5 Three-dimensional plot of the response surface for percentage of Eugenol of Piper Betle leaves

From the experimental data, the highest percentage of Eugenol obtained was $10.275 \%$ at low temperature and pressure with high flow of $\mathrm{CO}_{2}$ which were $40{ }^{\circ} \mathrm{C}, 10 \mathrm{MPa}$ and $8 \mathrm{~mL} / \mathrm{min}$. Fig. 5 shows three dimensional plot of the response surface for percentage of Eugenol in Piper Betle leaves extract for which the polynomial function is

$$
\begin{aligned}
& \% \text { Eugenol }=-68.127+24.709 \mathrm{f}+1.6505 \mathrm{~T}+ \\
& 1.7258 \mathrm{P}-0.2447 \mathrm{fT}-0.3109 \mathrm{fP}-0.0152 \mathrm{TP}
\end{aligned}
$$

As can be seen in Eq. 3, the flow rate of $\mathrm{CO}_{2}$ shows the most dominant parameter which contributes positive effect with the coefficient of 24.709 compared with pressure and temperature where the coefficient obtained is 1.7258 and 1.6505 . From the graph shown in Fig. 5, the effect of increasing flow rate of $\mathrm{CO}_{2}$ on the yield of Eugenol $\left(\mathrm{C}_{10} \mathrm{H}_{12} \mathrm{O}_{2}\right)$ was more obvious than that of temperature and pressure. The slope of the increases flow rate shows steeper compared to the increases pressure and temperature proves that flow rate was the most dominant factor on the Eugenol recovery of piper betel.

In supercritical fluid extraction process, flow rate of solvent is another factor that affecting the extraction process to produce a high yield of extracts [29]. From Fig. 5, it shows that by increasing the $\mathrm{CO}_{2}$ flow rate, the percentage of Eugenol also increased. This phenomenon occurs could be due to the reducing of mass transfer resistance of solute-solvent. Furthermore, by increasing the $\mathrm{CO}_{2}$ flowrate, the intermolecular interaction between solvent and the solute increase due to the increase of $\mathrm{CO}_{2}$ molecules per volume in the extraction vessel [29]. In this condition, the mass transfer increases as the flowrate increases.

However, as the pressure and temperature increased, the percentage of Eugenol decreased. The decreasing could be due to the degradation of the interest compound. As shown in Fig. 5, as the temperature constant at low condition which is $40^{\circ} \mathrm{C}$, the percentage of Eugenol increased as the pressure increase. This process occurs due to the improvement of oil solubility resulted from the increased carbon dioxide density with the rise of pressure.
Table 3 Analysis of Variance for oil yield and the percentage of Eugenol

\begin{tabular}{llllllll}
\hline Source & $\begin{array}{l}\text { Sum } \\
\text { of } \\
\text { Square }\end{array}$ & df & $\begin{array}{l}\text { Mean } \\
\text { Square }\end{array}$ & $\mathbf{F}_{\mathbf{c}}$ & $\mathbf{F}_{\mathbf{t}}$ & $\mathbf{R}_{\mathbf{2}}$ & $\mathbf{R}_{\mathbf{a}}$ \\
\hline Oil yield & & & & & & & \\
Regression & 0.065 & 9 & 0.0072 & 4.22 & 2.98 & 0.6906 & 0.54 \\
$\begin{array}{l}\text { Residual } \\
\text { Total }\end{array}$ & 0.029 & 17 & 0.0017 & & & & \\
& 0.094 & 26 & & & & & \\
$\%$ Eugenol & & & & & & & \\
$\begin{array}{l}\text { Regression } \\
\text { Residual }\end{array}$ & 4860.46 & 6 & 810.08 & 16.03 & 3.87 & 0.8279 & 0.78 \\
Total & 1010.53 & 20 & 50.53 & & & & \\
\hline
\end{tabular}

The results of the experimental parameters were measured by statistical analysis of the experimental data shown in Table 2. The enter method was used to calculate the estimated coefficients of the polynomial functions of response surfaces for both global oil yield and the amount of Eugenol extracted. The analysis of variance (ANOVA) is presented in Table 3 for global oil yield and the amount of Eugenol extracted in term of $\% \mathrm{w} / \mathrm{w}$.

Analysis of variance was performed as in Table 3. The result of oil yield for $\mathrm{F}$ value calculated was 4.22 while $\mathrm{F}$ value tabulated at $95 \%$ confidence level was $2.98(\mathrm{Fc}>\mathrm{Ft})$. Hence, there is significant relationship between the parameters. The calculated coefficient of correlation $\left(\mathrm{R}^{2}\right)$ and adjusted coefficient of correlation $\left(\mathrm{R}^{2} \mathrm{a}\right)$ were $69.06 \%$ and $54.0 \%$ respectively. These values show that the model satisfactorily represented the experimental data and $54.0 \%$ of the variations could be covered by the fitted model Eq. 2 .

Meanwhile, for the percentage of Eugenol, the result of percentage of Eugenol for $F$ value calculated was 16.03 while $F$ value tabulated at $95 \%$ confidence level was $3.87(\mathrm{Fc}>\mathrm{Ft})$. Hence, there is significant relationship between the parameters. The calculated coefficient of correlation $\left(\mathrm{R}^{2}\right)$ and adjusted coefficient of correlation $\left(\mathrm{R}^{2} \mathrm{a}\right)$ were $82.79 \%$ and $78.0 \%$ respectively. These values show that the model satisfactorily represented the experimental data and $78.0 \%$ of the variations could be covered by the fitted model Eq. 3. The analysis indicated that both models were statistically significant at $95 \%$ confidence.

\section{CONCLUSION}

In this study, an experimental design was performed in order to optimize three important parameters of $\mathrm{SC}-\mathrm{CO}_{2}$ extraction which are temperature $\left(40-80{ }^{\circ} \mathrm{C}\right)$, pressure $(10-30 \mathrm{MPa})$ and flowrate $\mathrm{CO}_{2}(4-8$ $\mathrm{mL} / \mathrm{min}$ ), using RSM. The main objective of this research was to determine the optimum operating conditions of $\mathrm{SC}_{-} \mathrm{CO}_{2}$ for the extraction of global oil and Eugenol from piper betel leaves. The best conditions to maximize both responses which were the global oil yield and amount of Eugenol were $40.0{ }^{\circ} \mathrm{C}, 19 \mathrm{MPa}$ and $7.00 \mathrm{~mL} / \mathrm{min}$. which lead to $0.228 \mathrm{~g}$ of global oil yield and $8.21 \%$ in terms of amount of Eugenol in the extracts. The results show a good fit to the proposed model and the optimal conditions obtained were within the experimental range with the value of $\mathrm{R}^{2}$ was $69.06 \%$ for global oil yield and $82.79 \%$ for amount of Eugenol.

\section{ACKNOWLEDGEMENT}

This research is fully supported by the Ministry of Higher Education, Malaysia (MOHE) [Fundamental Research Grant Scheme Number R. J130000.7809.4F766]. The authors fully acknowledged (MOHE) and Universiti Teknologi Malaysia for the approved fund which makes this important research viable and effective. 


\section{REFERENCES}

[1] Suryasnata, D., Reena P., Sriram S., Sanghamitra N. and Sujata M. 2016. Biotechnological Intervention in Betelvine (Piper betle L.): A Review on Recent Advances and Future Prospects. Asian Pacific J. of Tropical Med. 9(10): 938-946.

[2] Arsad, N. H., Yunus, M. A. C., Ahmad Zaini, M. A., Rahman, Z. A. and Idham, Z. 2016. Effect of Operating Conditions of Supercritical Carbon Dioxide on Piper Betle Leave Oil Yield and Antioxidant Activity. Inter J. of Appl. Chem. 12(4): 741-751.

[3] Guha P. 1997. Exploring Betel Leaves for Cottage Industry. In Krishi, Khadya-O-Gramin Bikash Mela (Eds.). Agric. and Food Eng. Department, IIT, Kharagpur. 15-19.

[4] Maity, S. 1989. Extension Bulletin: The Betel Vine. All India Coordinated Research Project on Betel Vine, Indian Institute of Horticultural Research, Hessarghatta, Bangalore, India. 16.

[5] Samanta, C. 1994. A Report on the Problems and Solutions of Betel Vine Cultivation. A booklet published by Mr. H. R. Adhikari, C-2/16, Karunamoyee, Salt Lake City, Kolkata-64 (WB), India.

[6] Stöhr, J. R., Xiao, P. G. and Bauer, R. 2001. Constituents of Chinese Piper Species and Their Inhibitory Activity on Prostaglandin and Leukotriene Biosynthesis In-Vitro. J. of Ethnopharmacol. 75(2-3): 133139.

[7] Sarkar, D., Saha, P., Gamre, S., Bhattacharjee, S., Hariharan, C., Ganguly, S. 2008. Anti-inflammatory Effect of allylpyrocatechol in LPS-Induced Macrophages is Mediated by Suppression of iNOS and COX-2 via the NF-kB Pathway. Inter. Immunopharmacol. 8(9): 1264 1271.

[8] Flores, N., Jimannez, I. A., Gimralnez, A., Ruiz, G., Gutianrrez, D., Bourdy, G., Bazzocchi, I. L. 2009. Antiparasitic Activity of Prenylated Benzoic Acid Derivatives from Piper Species. Phytochem. 70(5): 621627.

[9] Parmar, V. S., Jain, S. C., Bisht, K. S., Jain, R., Taneja, P., Jha, A., Tyagi, O. D., Prasad, A. K., Wengel, J., Olsen, C. E., Boll, P. M. 1997. Phytochemistry of the Genus Piper. Phytochem. 46: 597-673.

[10] Beuchat, L. R., Golden, D.A. 1989. Antimicrobials Occurring Naturally in Foods. Food Tech. 43: 134-142

[11] Cowan, M. M. 1999. Plant Products as Antimicrobial Agents. Clinical Microbiol. Rev. 12: 564.

[12] P. Dubey and S.C. Tripathi, Z. 1987. Pflanzenkrankh. Pflanzenschutz. 94(3): 235.

[13] Handa, S. S., Kaul, M. K. 1997. Suppliment to Cultivation and Utilization of Aromatic Plants. Reg. Res. Lab. Jammu Tawi, India. 506507.

[14] Right, D. A., Payne, J. P. 1962. A Clinical Study of Intravenous Anesthesia with a Eugenol Derivative. British J. of Anesthesia. 34: 379385.

[15] Felix-Valenzyela, L., Higuera-Ciapara, I. and Goycoolea-Valencia, F. 2001. Supercritical $\mathrm{CO}_{2}$ /ethanol of Astaxanthin from Blue Crab (Callinectes sapidus) Shell Waste. J. of Food Process Eng. 24: 101-112.
[16] Wang, H., Chen, C. Chang, C. 2001. Carbon Dioxide Extraction of Ginseng Root Hair Oil and Ginsenosides. Food Chem. 72: 505-509.

[17] Mendes, R., Nobre, B., Cardoso, M., Pereira, A., Palavra, A. 2003. Supercritical Carbon Dioxide Extraction of Compounds with Pharmaceutical Importance from Microalgae. Inorganica Chimica Acta. 356: 328-334.

[18] Tonthubthimthong, P., Chuaprasert, S., Douglas, P., Luewisutthichat, W. 2001. Supercritical $\mathrm{CO}_{2}$ Extraction of Nimbin from Neem Seeds An Experimental Study. J. of Food Eng. 47: 289-293.

[19] Mohd, A. C. Y., Nur, H. A., Salman, Z., Zuhaili, I., Siti, H. S., Ana, N. M. 2013. Effect of Supercritical Carbon Dioxide Condition on Oil Yield and Solubility of Pithecellobium Jiringan (Jack) Prain Seeds. Jurnal Teknologi. 60: 45-50.

[20] Dhungana, P., Eskridge, K. M., Weiss, A. and Baenziger, P. S. 2006. Designing Crop Technology for a Future Climate: An Example Using Response Surface Methodology and the CERES - Wheat Model. Agric. Syst. 87: 63-79.

[21] Bas, D., Boyac, I.H. 2007. Modeling and Optimization: Usability of Response Surface Methodology. J. of Food Eng. 78(3): 836-845.

[22] Sivaraosa, Milkey, K. R., Samsudin, A. R., Dubey, A. K. and Kidd, P. 2014. Comparison between Taguchi Method and Response Surface Methodology (RSM) in Modelling $\mathrm{CO}_{2}$ Laser Machining. Jordan J. of Mech. and Ind. Eng. 8(1): 35-42.

[23] Pathirana, C. L. and Shahidi, F. 2005. F. Optimization of Extraction of Phenolic Compounds from Wheat Using Surface Response Methodology. Food Chem. 93: 47-56.

[24] Hartati, Salleh, L. M., Mohd Yunus, A. C. and Aziz, A. A. 2014. Optimization of Supercritical $\mathrm{CO}_{2}$ extraction of Swietenia Mahagoni Seed by Response Surface Methodology. Jurnal Teknologi (Sciences and Engineering). 67(1): 15-20.

[25] Salleh, L. M., Abel, S. E. R., Zahedi, G., Rahman, R. A., Nasir, H. M. and Faua'ad, S. A. S. 2015. Optimization of Supercritical Carbon Dioxide Extraction of Quercus infectoria Oil. Jurnal Teknologi. 74(7): 79-86.

[26] Yunus, M. A. C., Idham, Z. B., Morad, N. A. 2015. Optimisation of Squalene from Palm Oil Mesocarp Using Supercritical Carbon Dioxide. 10th Asian Control Conference (ASCC), 2015. Kota Kinabalu, Malaysia. 31 May - 3 June 2015. 7244910.

[27] Lee, W. Y., Cho, Y. J., Oh, S.L., Park, J. H., Cha, W.S., Jung J.Y. 2000. Extraction of Grape Seed Oil by Supercritical $\mathrm{CO}_{2}$ and Ethanol Modifier. Food Sci. Biotech. 9: 174-178.

[28] Leo, L., Rescio, L., Ciurlia, L., Zacheo, G. 2005. Supercritical Carbon Dioxide Extraction of Oil and $\alpha$ - tocopherol from Almond Seeds $J$. Sci. Food Agric. 85: 2167-2174.

[29] Machmudah, S., Kawahito, Y., Sasaki, M., Goto, M. 2007. Supercritical $\mathrm{CO}_{2}$ Extraction of Rosehip Seed Oil: Fatty Acids Composition and Process Optimization. J. Supercrit. Fluids. 41: 421-428. 